\title{
The Influence of Organizational Pride on the Performance of Lecturers in Health at the Nahdlatul Ulama University in Surabaya
}

\author{
Ima Nadatien ${ }^{1}$, Seger Handoyo ${ }^{2}$, Widodo J. Pudjirahardjo ${ }^{3}$, Yusti Probowati ${ }^{4}$ \\ ${ }^{1}$ Prodi Magister of Nursing, Nursing Faculty and Midwifery Nahdlatul Ulama University of Surabaya; \\ ${ }^{2}$ Psicology Faculty, ${ }^{3}$ Public Health Faculty, Airlangga University of Surabaya; ${ }^{4}$ ssicology Faculty of \\ Surabaya University of Surabaya
}

\begin{abstract}
Pride is needed in individual motivation and performance, because a person will respond to profitable identities, which are relevant to developing members' psychological sense in the organization, as identification or commitment (Tyler \& Blader, 2003). Unusa is a college concentrating on health education programs. Data from Unusa regarding the dharma of conducting research and community service in 2014, found that out of 117 lecturers who had carried out the research, the number had only reached $42,7 \%$, community service was $44,4 \%$. Demonstrating the performance of Unusa lecturers is not optimal. Research objectives, to prove the influence of Organizational Pride on the Performance of Unusa Lecturers. Observational research design, type of explanatory research, using a cross sectional approach. Respondents were 105 lecturers. Independent variables are Organizational Pride. Dependent variables are Lecturer Performance (task performance, contextual performance, adaptive performance, counterproductive work behavior). Data analysis used linear regression test, $\alpha=0.05$. The results of the study prove that Organizational Pride influences Lecturer Performance $(p=0.002 ; b=0.301)$. This study shows that Pride of the Organization can play a role in encouraging the increase of Lecturer Performance. The higher the Pride of the Organization ultimately increases the Lecturers' Performance. Efforts to strengthen the pride of the lecturers, individually and in institutions are carries out through training and SGD (Small Group Discussion) with routine. Finally, it will improve and strengthen the sense of love, belonging and loyal to optimize the performance of the tridharma.
\end{abstract}

Keywords: Organizational Pride, Lecturers' Performance

\section{INTRODUCTION}

Pride is part of the organization. According to Tyler and Blader, Pride is a belief in an individual who refers to the way he evaluates his organization without making explicit comparisons with other organizations ${ }^{1}$.

Pride belongs to everyone who feels proud to be a member or part of an organization. Individuals feel proud to use all the attributes of the organization every day. The pride attitude of individuals who feel the organization supports the individual and gives positive value to him.

\section{Correspondence Author:}

Ima Nadatien

Prodi Magister of Nursing, Nursing Faculty and Midwifery

Nahdlatul Ulama University of Surabaya

Email: iman.69@unusa.ac.id
Individuals feel that the organization has important and beneficial meaning for individuals as members of the organization. Conversely, No pride in the individual who feels that his organization gives a negative value to him as a member of the organization.

Performance is the level of success in carrying out tasks and the ability to achieve predetermined goals ${ }^{2}$. Associated with the role of individuals in the organization, performance is a series of individual behaviors or activities that are in line with the expectations or desires of the organization in which he works ${ }^{3}$.

According to Steers and Porter(1987) that performance is influenced by individual motives in interacting with their environment. Performance can be express as an expression of the potential behavior or way of someone in carrying out a task, is a manifestation of the duties and responsibilities of the work given. 
Individual performance is work performance measured by actual achievement compared to the expected performance of employees. Expected work performance is standard achievement as a reference. Proving employee performance in accordance with the standard or other employees ${ }^{4}$.

Individual performance is the foundation of organizational performance, so it is necessary to understand individual behavior that also greatly influences organizational behavior in realizing effective management. Organizational behavior is strongly influence by individual characteristics, individual motivation and appreciation. Besides that, there are several behavioral processes that can influence and give color to the life of the organization. According to John M. Ivancevich, et al (2007) processes that contribute to effective organizational performance include communication, decision making and leadership. The sustainability of an organization depends on the ability of management to receive, send and follow up on information. The communication process connects individuals and integrates internal activities from the organization. Information also integrates organizational activities with external requests. In addition, communication and feedback are management approaches in decision making in organizations.

In this study, using the results of research from Linda Koopmans, et all entitled Conceptual Frameworks of Individual Work Performance A Systematic Review to measure or identify individual performance indicators. It done because the dimensions of this study include Task Performance, Contextual Performance, Adaptive Performance, and Counterproductive Work Behavior.

1. Task Performance: Task performance as an important dimension of individual work performance. Task Performance as an ability (competence) which to perform central work tasks. Task performance is a specific work of the technical ability of task skills or role performance such as work quantity, work quality, and knowledge work. Includes completing work assignments, work quality, work quantity, work skills, job knowledge, keeping up to date knowledge, working accurately and neatly, planning and organizing, administration, decision making, problem solving, oral and written communication, monitoring and controlling resource.
2. Contextual Performance: Contextual performance as individual behavior that supports organization, social interaction and psychological environmental functions. Behavioral-oriented beyond the specified official work goals. Contextual Performance, including Extra tasks, Effort Initiative, Enthusiasm, Attention to duty, Resourcefulness, Industriousness, Persistence, Motivation, Dedication, Proactivity, Creativity, Cooperating with and helping others, Politeness, Effective communication, Interpersonal relations, Organizational commitment.

3. Adaptive Performance: Adaptive performance is an individual's adjustment to changes in the work system or job role. These conditions and situations include creative problem solving, dealing with uncertain or unpredictable work situations, learning new tasks, technology and procedures, and adapting to others, culture, or the physical environment.

Adaptive Performance, including generating new, innovative ideas, adjusting goals and plans to situations, learning new tasks and technologies, understanding and others, understanding other groups or cultures, showing resilience, remaining calm, analyzing quickly, acting appropriately.

4. Counterproductive Work Behavior: Counterproductive work behavior as a behavior is detrimental to organizational welfare, becoming a phenomenon that can be found in the work environment and occurs in almost all organizations with different intensities.

Counterproductive Work Behavior can be described in the following activities, Off task behavior, Too many or longer breaks, Presentism, Absenteeism, Complaining, Tardiness, incorrectly, Accidents, Insult or gossiping about coworkers, Fighting or arguing with coworkers, Disregard of safety, Misusing privileges, Aggression, Theft, Substance use.

\section{OBJECTIVE}

Analyzing the influence of Organizational Pride on Unusa lecturer performance (Task performance, Contextual performance, Adaptive performance, Counterproductive work behavior). 


\section{METHOD}

The method used in this study is observational analytic, using an explanatory type. The study explores the causal effects of Organizational Pride and lecturer performance. Based on the time of data collection, using cross sectional. Respondents were 105 lecturers at Unusa's study program. The variables studied include independent variables, namely Organizational Pride. The dependent variable is the performance of the lecturer. The instrument used was a questionnaire. Data analysis used linear regression test. Retrieval of data using a questionnaire.

\section{RESULT}

The results of the study describe the description of measurement and statistical analysis of the variables of Organizational Pride and Performance.

Pride Description of Unusa lecturer organizations: The pride of the Unusa Organization uses 3 indicators, namely the pride of being a lecturer at Unusa because of the value of NU, the feeling of being proud as an Unusa lecturer internally, and the feeling of being happy to meet other people as Unusa lecturers. Each indicator is a sub variable. Results of review of Pride variables Different attitudes were seen in table 1

Table 1: Description of Composite Measurement Variable Pride of Unusa lecturer organization in 2016

\begin{tabular}{|c|c|c|c|c|c|c|c|}
\hline \multirow{2}{*}{ No. } & Pride of the Organization & \multicolumn{3}{|c|}{ Criteria } & \multirow{2}{*}{ Total } & \multirow{2}{*}{ Mean } & SD \\
\cline { 3 - 4 } & Low & Enough & High & & \\
\hline 1. & $\begin{array}{c}\text { Sense of Proud to be a lecturer at } \\
\text { Unusa because of the NU Value }\end{array}$ & 0 & $49(46,7 \%)$ & $56(53,3 \%)$ & $105(100 \%)$ & 2,53 & 0,50 \\
\hline 2. & $\begin{array}{c}\text { Sense of Proud to be a lecturer at } \\
\text { Unusa Internally }\end{array}$ & $1(1,0 \%)$ & $57(54,3 \%)$ & $47(44,8 \%)$ & $105(100 \%)$ & 2,44 & 0,52 \\
\hline 3. & $\begin{array}{c}\text { A feeling of pleasure when people see } \\
\text { as Unusa lecturers }\end{array}$ & 0 & $53(50,5 \%)$ & $52(49,5 \%)$ & $105(100 \%)$ & 2,50 & 0,50 \\
\hline & Pride of the Organization & 0 & $48(45,7 \%)$ & $57(54,3 \%)$ & $105(100 \%)$ & 2,54 & 0,50 \\
\hline
\end{tabular}

Source: Primary research data, 2016

In table 1, it can be seen that Unusa lecturers have sufficient organizational pride (average 2.54). Proud of being a lecturer at Unusa because the NU value has the highest average of others. This shows that the lecturer is proud of the value of NU that is applied, not proud of being part of the organization (Unusa). Even then, it indicated by the average category

Unusa Lecturer Performance: Lecturer performance as a lecturer's behavior carries out tridharma according to the standards of implementing Unusa lecturer workload, which is detailed in Task performance, Contextual performance, Adaptive performance, Counterproductive work behavior. Explanation of each lecturer performance indicator in the table 2

Table 2: Composite Descriptions of Unusa lecturers' performance in 2016

\begin{tabular}{|c|c|c|c|c|c|c|c|}
\hline \multirow{2}{*}{ No. } & \multirow{2}{*}{ Lecturer's Performance } & \multicolumn{3}{|c|}{ Criteria } & \multirow{2}{*}{ Total } & \multirow{2}{*}{ Mean } & \multirow{2}{*}{ SD } \\
\cline { 3 - 6 } & & Low & Enough & High & & & \\
\hline 1. & Task Performance & $4(3,8 \%)$ & $14(13,3 \%)$ & $87(82,9 \%)$ & $105(100 \%)$ & 2,79 & 0,49 \\
\hline 2. & Contextual Performance & $4(3,8 \%)$ & $10(9,5 \%)$ & $91(86,7 \%)$ & $105(100 \%)$ & 2,83 & 0,47 \\
\hline 3. & Adaptive Performance & $4(3,8 \%)$ & $14(13,3 \%)$ & $87(82,9 \%)$ & $105(100 \%)$ & 2,79 & 0,49 \\
\hline 4. & Counterproductive Work Behavior & 0 & $13(12,4 \%)$ & $92(87,6 \%)$ & $105(100 \%)$ & 2,88 & 0,33 \\
\hline & Kinerja Dosen & 0 & $16(15,2 \%)$ & $89(84,8 \%)$ & $105(100 \%)$ & 2,85 & 0,36 \\
\hline
\end{tabular}

Source: Primary research data, 2016 
Table 2 provides a real picture of the performance of Unusa lecturers in implementing tridharma in sufficient categories (2.85). This means that Unusa lecturers have done enough tridharma obligations on task performance, contextual performance, adaptive performance and not doing Counterproductive Work Behavior, which is a unified indicator of lecturer performance in this study. Thus, Unusa lecturers work quite well in carrying out learning, research and community service activities. Lecturers are expected to be able to control themselves and not emotionally, or not show Counterproductive Work Behavior when they are in a situation of workload pressure or unfavorable conditions and disrupt the implementation of tridharma.

Linear Regression test results prove that there is a significant effect of Organizational Pride on Lecturer Performance with $p=0.002$. The value of $b=0.301$ indicates that Organizational Pride can play a role in encouraging an increase in Lecturer Performance with a contribution of $30.1 \%$. This means that, there are other factors beside Organizational Pride that can improve Lecturer Performance with a contribution of $69.9 \%$.

\section{DISCUSSION}

The contribution of Organizational Pride to Lecturer Performance is $30.1 \%$, which is a positive impact of the sense of leadership towards Unusa. A sense of pride in Unusa can occur internally and be recognized by Unusa's performance and competitiveness as a university in the middle of other universities. If Unusa's work and competitiveness is still uncovered, it will be difficult to have pride.

Another factor that can improve Lecturer Performance with a contribution of $69.9 \%$, including the ability of lecturers to master their competence. In accordance with Amanta Law number 14 of 2005 concerning Teachers and Lecturers, that lecturer competence includes pedagogic competence, professional competence, personality competence, and social competence. This competence is a requirement to be an educator or lecturer and can be deepened by attending lecturer competency training.

The concept put forward by Tyler and Blader, Cooperation in Groups: Procedural Justice, Social Identity, and Behavior Engagement, Pride is as a belief in a person or individual that refers to the way an individual or someone evaluates his organization without making explicit comparisons with other organizations. A proud attitude of being part of an organization provides positive value, so that it can spur the spirit of carving out one's achievements. The proud attitude of the lecturer who feels Unusa lives and gives positive value to him, so that anything that comes into with Unusa, the lecturer will appear proud. However, if anyone tries to harass Unusa in various ways, he will try his best to defend. In fact, when someone harasses and attacks Unusa, it will be desperate to defend Unusa.

If the achievements and competitiveness of Unusa are still not felt by the lecturer, then the lecturer will be difficult to have pride.

Pride of the part of the organization, according to Tyler and Blader, is as a belief in the individual who refers to the way individuals evaluate their organization without making explicit comparisons with other organizations ${ }^{5}$.

Pride is with everyone who feels lucky and likes to be a member or part of the organization. Individuals feel proud to use all the attributes of the organization every day. The proud attitude of individuals who feel the organization supports the individual and gives positive value to him. Individuals feel that the organization has important and beneficial meaning for individuals as members of the organization. Pride will not exist in individuals who feel that the organization gives a negative value to itself as a member of the organization.

According to M. Shamsul Haque, in his book Pride and Performance in The Public Service Three Asian Cases. SAGE Journals, International review of administrative sciences, It was stated that one's pride in the organization has implications from the motivation and commitment needed by the organization which is an intrinsic factor.

By having pride in the organization, the lecturer feels Unusa has an important and beneficial meaning. Pride is an attitude observed in the lecturer in carrying out Tridharma activities in Unusa. Thus, pride can be seen as a powerful motivator. Lecturers, who are proud of working, for what have done and for whom the lecturer works. Furthermore, pride increases teamwork, as partners treat each other with respect ${ }^{6}$. 
Lecturers who are proud of Unusa, have positive attitudes towards fellow lecturers and other Unusa members, strengthen the sense of togetherness and willingness to act more than what is supposed to be done. This condition is effective to foster a sense of ownership in the organization, as a lecturer as capital to nourish the life of the organization and develop it.

The sense of belonging to this organization can thicken the life of the lecturer, especially to do everything; that is good a lecturer not always driven by everything that benefits him.

\section{CONCLUSIONS}

The conclusion of the study is that the higher the Pride of the Organization will ultimately increase the Lecturers' Performance. Lecturers feel Unusa has important and beneficial meaning. Pride is an attitude observed in the lecturer in carrying out Tridharma activities in Unusa.

Thus, pride can be seen as a powerful motivator. Employees, for example, are proud of working, what they do and who they work for. Furthermore, pride increases teamwork, as partners treat each other with respect.

Ethical Clearance: Taken from ethic committee Nahdlatul Ulama University of Surabaya

Source of Funding: Self Funding

Conflict of Interest: There aren't any relevant conflict of interest

\section{REFERENCE}

1. Tyler, T. R. \& Blader, S. L., The Group Engagement Model: Procedural Justice, Social Identity, and Cooperative Behavior. Personality and Social Psychology Review, 2003. Volume 7, pp. 349-361.

2. Goodhue, D. L. \& Thompson, R. L. Tasktechnology Iit individual Performance. 1995. MIS Quarterly, 9(2), pp. 213-236.

3. Aaron C. Weidman1, Jessica L. Tracyl, and Andrew J. Elliot2. Pride-as-BarometerEffect 1University of British Columbia; 2013. University, http://ubc-emotionlab.ca /wp-content/ uploads/2011/12/Weidman-Tracy-Elliot.
4. Koopmans Linda, Claire M. Bernaards, $\mathrm{PhD}$, Vincent H. Hildebrandt, PhD, Wilmar B. Schaufeli, PhD, Henrica C.W. de Vet, PhD, and Allard J. van der Beek, PhD. JOEM. Conceptual Frameworks of Individual Work Performance, 2011. Volume 53, Number 8, August 2011

5. Tyler, T. R. \& Blader, S. L.. Cooperation in Groups: Procedural Justice, Social Identity, andbehavior Engagement. Philadelphia, PA: Psychology Press. 2002.

6. Katzenbach, J. R. Pride: a strategic asset. Journal of Strategy \& Leadership ,2003. 31(5), pp. 34-38.

7. Boezeman, E. \& Ellemers. Pride and respect in volunteers organizational commitment. European Journal of Social Psychology, 2008. Volume 38, pp. 159-172.

8. Kupprlwieser, V. G., Grefrath, R. \& Dziuk, A. A Classification of Brand Pride Using Trust and Commitment. Journal of Business and Social, 2011.

9. Nadatien, Ima. Pengaruh Nilai Bersama NU, Kebanggaan Organisasi, Perilaku Kewargaan Organisasi terhadap Kinerja Dosen di Universitas Nahdlatul Ulama Surabaya, Disertasi, Surabaya, Universitas Airlangga. 2018.

10. Singarimbun, M., Metode Penelitian Survei. Jakarta : LPS3ES.1994.

11. Suharjo, B. Analisis Regresi Terapan SPSS. Yogyakarta : Graha Ilmu. 2008

12. Tracy, J. L. \& Robins, R. W. The psychological structure of pride: A tale of two facets. Journal of Personality and Social Psychology, 2007. 92(3), pp. 506-525.

13. Trihendradi, C. SPSS 13: Step by step Analisis Data Statistik. Yogyakarta: Andi. 2007

14. Volker G. Kuppelwieser, Robert Grefrath, Agathe Dziuk, a University of Wuppertal, Schumpeter Business School, Chair of Retail and Service Management, Gaussstr. 20, 42097 Wuppertal. International Journal of Business and Social Science Vol. 2 No. 3 [Special Issue January2011],www.ijbssnet.com/journals/Vol../3 


\section{Volume 10 Number 1 January 2019}

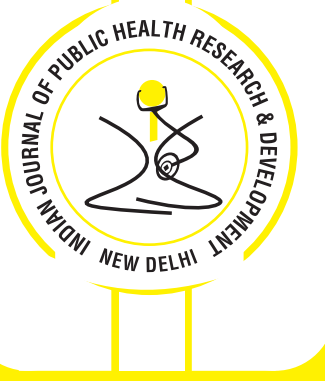

\section{Indian Journal of}

\section{Public Health Research \& Development}

An International Journal

\section{SCOPUS IJPHRD CITATION SCORE}

Indian Journal of Public Health Research and Development Scopus coverage years: from 2010 to 2018 Publisher: R.K. Sharma, Institute of Medico-Legal Publications ISSN:0976-0245E-ISSN: 0976-5506 Subject area: Medicine:

Public Health, Environmental and Occupational Health

Cite Score 2017- 0.03

SJR 2017- 0.108

SNIP 2017- 0.047

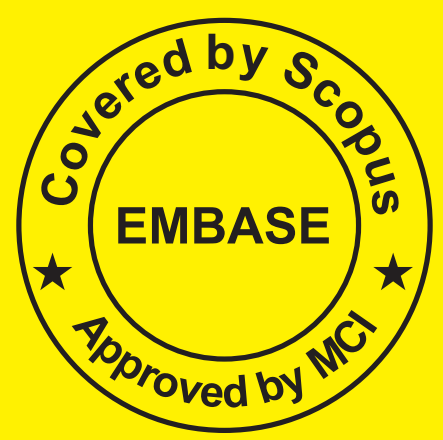

Website:

www.ijphrd.com 


\title{
Indian Journal of Public Health Research \& Development EXECUTIVE EDITOR
}

\author{
Prof Vidya Surwade
}

Associate Professor, Dr Baba Saheb Ambedkar,Medical College \& Hospital, Rohinee, Delhi

\section{INTERNATIONAL EDITORIAL ADVISORY BOARD}

1. Dr. Abdul Rashid Khan B. Md Jagar Din, (Associate Professor) Department of Public Health Medicine, Penang Medical College, Penang, Malaysia

2. Dr. V Kumar (Consulting Physician) Mount View Hospital, Las Vegas, USA

3. Basheer A. Al-Sum, Botany and Microbiology Deptt, College of Science, King Saud University, Riyadh, Saudi Arabia

4. Dr. Ch Vijay Kumar (Associate Professor) Public Health and Community Medicine, University of Buraimi, Oman

5. Dr. VMC Ramaswamy (Senior Lecturer) Department of Pathology, International Medical University, Bukit Jalil, Kuala Lumpur

6. Kartavya J. Vyas (Clinical Researcher) Department of Deployment Health Research, Naval Health Research Center, San Diego, CA (USA)

7. Prof. PK Pokharel (Community Medicine) BP Koirala Institute of Health Sciences, Nepal

\section{NATIONAL SCIENTIFIC COMMITTEE}

1. Dr. Anju Ade (Associate Professor) Navodaya Medical College, Raichur,Karnataka

2. Dr. E. Venkata Rao (Associate Professor) Community Medicine, Institute of Medical Sciences \& SUM Hospital, Bhubaneswar, Orissa.

3. Dr. Amit K. Singh (Associate Professor) Community Medicine, VCSG Govt. Medical College, Srinagar - Garhwal, Uttarakhand

4. Dr. R G Viveki (Professor \& Head) Community Medicine, Belgaum Institute of Medical Sciences, Belgaum, Karnataka

5. Dr. Santosh Kumar Mulage (Assistant Professor) Anatomy, Raichur Institute of Medical Sciences Raichur(RIMS), Karnataka

6. Dr. Gouri Ku. Padhy (Associate Professor) Community and Family Medicine, All India Institute of Medical Sciences, Raipur

7. Dr. Ritu Goyal (Associate Professor) Anaesthesia, Sarswathi Institute of Medical Sciences, Panchsheel Nagar

8. Dr. Anand Kalaskar (Associate Professor) Microbiology, Prathima Institute of Medical Sciences, AP

9. Dr. Md. Amirul Hassan (Associate Professor) Community Medicine, Government Medical College, Ambedkar Nagar, UP

10. Dr. N. Girish (Associate Professor) Microbiology, VIMS\&RC, Bangalore

11. Dr. BR Hungund (Associate Professor) Pathology, JNMC, Belgaum.

12. Dr. Sartaj Ahmad (Assistant Professor), Medical Sociology, Department of Community Medicine, Swami Vivekananda Subharti University, Meerut,Uttar Pradesh, India

13. Dr Sumeeta Soni (Associate Professor) Microbiology Department, B.J. Medical College, Ahmedabad, Gujarat,India

\section{NATIONAL EDITORIAL ADVISORY BOARD}

1. Prof. Sushanta Kumar Mishra (Community Medicine) GSL Medical College - Rajahmundry, Karnataka

2. Prof. D.K. Srivastava (Medical Biochemistry) Jamia Hamdard Medical College, New Delhi

3. Prof. M Sriharibabu (General Medicine) GSL Medical College, Rajahmundry, Andhra Pradesh

4. Prof. Pankaj Datta (Principal \& Prosthodentist) Indraprastha Dental College, Ghaziabad

\section{NATIONAL EDITORIAL ADVISORY BOARD}

5. Prof. Samarendra Mahapatro (Pediatrician) $\mathrm{Hi}$-Tech Medical College, Bhubaneswar, Orissa

6. Dr. Abhiruchi Galhotra (Additional Professor) Community and Family Medicine, All India Institute of Medical Sciences, Raipur

7. Prof. Deepti Pruthvi (Pathologist) SS Institute of Medical Sciences \& Research Center, Davangere, Karnataka

8. Prof. G S Meena (Director Professor) Maulana Azad Medical College, New Delhi

9. Prof. Pradeep Khanna (Community Medicine) Post Graduate Institute of Medical Sciences, Rohtak, Haryana

10. Dr. Sunil Mehra (Paediatrician \& Executive Director) MAMTA Health Institute of Mother \& Child, New Delhi

11. Dr Shailendra Handu, Associate Professor, Phrma, DM (Pharma, PGI Chandigarh)

12. Dr. A.C. Dhariwal: Directorate of National Vector Borne Disease Control Programme, Dte. DGHS, Ministry of Health Services, Govt. of India, Delhi

Print-ISSN: 0976-0245-Electronic-ISSN: 0976-5506, Frequency: Quarterly (Four issues per volume)

Indian Journal of Public Health Research \& Development is a double blind peer reviewed international journal. It deals with all aspects of Public Health including Community Medicine, Public Health, Epidemiology, Occupational Health, Environmental Hazards, Clinical Research, and Public Health Laws and covers all medical specialties concerned with research and development for the masses. The journal strongly encourages reports of research carried out within Indian continent and South East Asia.

The journal has been assigned International Standards Serial Number (ISSN) and is indexed with Index Copernicus (Poland). It is also brought to notice that the journal is being covered by many international databases. The journal is covered by EBSCO (USA), Embase, EMCare \& Scopus database. The journal is now part of DST, CSIR, and UGC consortia.

Website : www.ijphrd.com

CAll right reserved. The views and opinions expressed are of the authors and not of the Indian Journal of Public Health Research \& Development. The journal does not guarantee directly or indirectly the quality or efcacy of any product or service featured in the advertisement in the journal, which are purely commercial.

Editor

Dr. R.K. Sharma

Institute of Medico-legal Publications

Logix Office Tower, Unit No. 1704, Logix City Centre Mall, Sector- 32, Noida - 201301 (Uttar Pradesh)

Printed, published and owned by

Dr. R.K. Sharma

Institute of Medico-legal Publications Logix Office Tower, Unit No. 1704, Logix City Centre Mall, Sector- 32, Noida - 201301 (Uttar Pradesh)

Published at

Institute of Medico-legal Publications

Logix Office Tower, Unit No. 1704, Logix City Centre Mall, Sector- 32, Noida - 201301 (Uttar Pradesh) 


\section{Indian Journal of Public Health Research \& Development}

www.ijphrd.com

Volume 10, Number 1

January 2019

1. A study to Assess the Knowledge Regarding the Care of Patients on Mechanical Ventilation and Prevention of VAP among Nursing Students of a Selected Nursing College 1 A S Saritha

2. A Study on Job Satisfaction among Employees in Quick Service Restaurants 5 A. Arun, J. Yuvaraj, A. Wilfred Lawrence

3. Comparitive Evaluation of the Fluoride Release and Rechargability of Chitosan Modified Glass Ionomer Cement and a Glass Ionomer Cement-An in Vitro Study Binsy Mathew, Abi M Thomas, Rajesh kumar

4. A Study on Determinants of Agricultural Productivity in Tamilnadu 14 C. K. Gomathi, S. N. Sugumar

5. Susceptibility of Gender Entrepreneurship Gap in India-A Preview 18 Chandrachud. S, S. N. Sugumar, S. Thangamayan, S. Sudha

6. Analysis of Medical Tourism and its Economic Impact 21 MS. J. Revathi, S. Jansi Rani

7. Occurrence of Menstrual Irregularities among Adolescent Girls in Selected Area, Dehradun, Uttarakhand 27 Jyoti Kandpal, Mugdha Devi Sharan Sharma, Upma George

8. Mother's Knowledge on Nutrition and Incidence of Malnutrition 32 Kalpana Sawane, Sheetal Barde

9. Mortality Pattern amongst Patient Admitted in Tertiary Health Care Center, Rajnandgaon (C.G.) 35 Harshal Mendhe, Kiran Makade, Dhiraj Bhawnani, Daneshwar Singh

10. Effectiveness of Self-Instructional Module on Knowledge Regarding Post-Partum Psychiatric Disorders 41 Leeja Bonny Thomas, Anusha Pradhan

11. A Study to Evaluate the Effectiveness of Structured Teaching Programme on Obesity \& its Consequences among Adolescents in Selected Private High Schools in Pune 47 Mangesh V. Jabade, Manu Acha Roy

12. Assessment of the Awareness about Effects of Cell Phone Radiations amongst Students at Symbiosis International (Deemed University) Hill Base Campus 51 Anshika Nikita Singh, Neeti Sharma, Abhay Saraf, Samir Barve, Yatin Pimple

13. A Study to Estimate the Level of Physical Activity and Perceived Benefits and Barriers to Exercise among Women in Coastal Karnataka 57

Sneha Deepak Mallya, Pawan Kumar, Sravan Kumar Reddy T, Beulah Sarah James, Asha Kamath 
14. Effect of Dispositional Mindfulness on Perceived Stress Scores of Engineering Students:

An Empirical Study 63

Ranju Lal, Pramod Pathak, K. R. Chaturvedi, Payel Talukdar

15. Confocal LASER Scanning Microscopy (CLSM) for Evaluation of Endodontic Microflora-A Review ... 69 Laxmish Mallya, Kundabala M, Vinod Jathanna

16. Effective Recruitment and Selection System for the IT Software Industry in India 74 Ramkumar A., Rajini G.

17. A Study on Innovative Recruitment Techniques and It's Impact on Job Seekers .79 Ramkumar A., Rajini G.

18. Emotional Intelligence and Performance of Manager in Manufacturing Industries (With special reference to Automobile Industry)

S. Chandrachud, M. Thaiyalnayaki

19. Mechanically Induced Stump Dermatoses: High Prevalence Concern and Measures of Prevention 88 Salman Shaikh, Akshay Malhotra

20. A Study on Universal Precautions and Needle Stick Injuries among Nursing Staff in a Tertiary Care Hospital, Davangere Sandhya Rani Javalkar, Sanjana S N

21. Pattern of Employment and Consumption Expenditure in India 98 S. Jansirani, S. Sudha

22. A Study on Women Domestic Workers in M.g.r.nagar in Kanchipuram District S. Jansirani, S. Janifar Vinnarasi

23. Influence of Emotional Intelligence on Employee Performance among Seleced Restaurants, Chennai .. 106 V. Krishna Priya

24. Preferences and Problems of Agri-Based Enterprises of Guntur (A.P., India):

An Empirical Study of Farmers Advisory Committees Under Atma 111 Vineet Pandey, Fate Bahadur Singh

25. Effects of Strength Training Exercises on Physical Parameters and Quality of Life among Older Adults in Selected Geriatric Homes in Kerala, India 116 Nisha B S, Dhanyamol K S, Devika Shaji, Rebecca Seguin

26. Study of MRSA and ESBL Organisms Isolated from Infected Wounds Suresh P, V. Sreenivasulu Reddy, V. Praveen Kumar, P. Vamsimuni Krishna

27. Prevalence of Angles Malocclusion Traits in 7-16-Year-old School Children of Mewar Region, India .. 125 Pradeep Vishnoi, Tarulatha R Shyagali, Prabhuraj Kambalyal, Deepak P Bhayya, Rutvik Trivedi, Jyoti Jingar

28. A Study on Marketing Prospects in Promoting Cultural Tourism in Tamil Nadu 131 A. Arun, J. Yuvaraj, A. Wilfred Lawrence, Chittaranjan Srivastsava

29. An Objective and Subjective Evaluation of Dental Implant Impressions using Vinylsiloxanether and Polyether Impression Materials-An in Vivo Study 135 Divya Raigangar, Mahesh Mundathaje, Puneeth Hegde, Umesh Pai, Thilak Shetty, Sharon Saldanha, Shobha J Rodrigues 
30. Comparison of Serum Calcium Levels in Euthyroid, Subclinical and Overt Hypothyroid Women in the Tribal Belt of West Midnapore, West Bengal

Sanjay Vashisth, Alpana Chhetri

31. Role of Whistle Blowers in Health Care Industry: An Empirical Study ....

Aseervatham Achary, Amit Kumar Pandey, Suneel Mago, Jaya Yadav, Sanjeev Bansal

32. Management of Talons Cusp in a Primary Maxillary Central Incisor: A Rare Case Report

Ellana Jermiah Joseph, Anupama Nayak P, Arathi Rao

33. Two Way Analysis of GST : With Reference to Healthcare and Pharma Sector

Arun Gautam, Saurabh Sharma

34. Comparison of Serological Tests in the Diagnosis of Leptospirosis in a Tertiary

Care Hospital at Chidambaram, Tamilnadu, India .....

Balamuruganvelu Singaravelu, Sreenivasalu Reddy V, Saleel V. Maulingkar, Geethavani Babu,

S. Kamala kannan

35. Traditional Use of Medicinal Plants in Puducherry for Treatment of Urinary Tract Disorders 160

C. Kishore Kumar, R. Vijaya Kumar, R. Sridharan

36. Awareness of Cervical Cancer among HIV Positive Women in Southern India

Deepak Madi, Parul Gupta

37. Correlates of Hope and Depression among People Living with Human Immunodeficiency

Virus in Chhattisgarh State

Bansh Gopal Singh, Deepak Pandey

38. Vitamin C Intake Improve the Anthropometric Measurements, Lipid Profile and Atherogenic Indices in Obese and Non Obese Females

Ganesh H. Ghanwat, Ajit V. Sontakke

39. Effect of Vitamin C Supplementation on Insulin Resistance, $\beta$-cell Function and Insulin Sensitivity in Obese and Non Obese Individuals

Ganesh H. Ghanwat, Ajit V. Sontakke

40. Serum VEGF and TNF- $\alpha$ Correlate Bacterial Burden in Pulmonary Tuberculosis

Harish Bhat, Jeevan G Ambekar, Anand Kumar Harwalkar, Nilima Dongre, Kusal K Das

41. Online Sales Promotions of Herbal Products and Its Effectiveness towards Tanisha.com

M.Anbarasi, S. Praveen Kumar

42. Effects of Strength Training Exercises on Physical Parameters and Quality of Life among Older

Adults in Selected Geriatric Homes in Kerala, India

Nisha B S, Dhanyamol K S, Devika Shaji, Rebecca Seguin

43. Impact of Quality of Work Life Dimensions on Organizational Performance: With reference to Jute Industry in Andhra Pradesh and West Bengal, India

K. Hymavathi, K. S. Sekhara Rao

44. A Study on Customer Preferences on Green Marketing S. Sayeeda Jabeen, M. Kavitha 
45. Why Physician's Keep Coming Back to Telemedicine: Predicting Using Unsupervised Learning 216 Preeti Y Shadangi, Manoranjan Dash, Sunil Kar

46. Practicing the Strategies of Interpersonal Conflicts Management in Business Organisations to Accede Development and Effectiveness in Personal Health

Mitashree Tripathy, Itishri Sarangi

47. Comparative Performance Analysis of Selected Large Cap Mutual Funds in India 227 Mohammed Mujahed Ali

48. Study of Morbidity Pattern among Women Beedi Rollers Residing in Urban Area of Mangalore 233 Nanjesh Kumar S, Sanjeev Badiger, Avin B. R. Alva, Pavan Kumar, Rahul Hedge

49. Perception, Attitude and Practices Regarding Climate Change among College Students in Coastal South India 236

Rekha Thapar, Bhaskaran Unnikrishnan, Nithin Kumar, Prasanna Mithra, Vaman Kulkarni, Ramesh Holla, Darshan Bhagawan

50. Evaluation of Thyroid Hormone Levels Before and After Thyroidectomy 242 Arunachala D Edukondalu, Chakradhar. S, Yamuna devi V. R., Prabhakar Reddy E.

51. Impact of Ambidextrous Leadership on Firm Performance: A Study on IT Sector in Hyderabad, India . 247 Sahyaja Ch., K. S. Sekhara Rao

52. Prevalence of Halitosis among Preclinical Medical and Dental Students 253 Runki Saran, Saurabh Kumar, Bharath Rao K, Arul Amalan

53. The Effectiveness of Information, Education and Communication on Knowledge, Attitude, Practice Regarding Obesity among Adolescents at Selected Government Schools in Kancheepuram District ..... 257 Shanthi M., C. Kanniammal, Jaideep Mahendra, G. Valli

54. Various Online Marketing and Promotions Strategies to Improve the Validation Towards the Organic Products in the Pharmaceutical Sectors 263 M. Anbarasi, S. Praveen Kumar

55. Effect of Bidirectional Dyadic Association on Anxiety and Self Esteem among Patients Undergoing Mastectomy 270 Sruthi. M, Sr. Nirmala FCC

56. An Empirical Study to Improve the Service Quality for Geriatric Patients in a Tertiary Care Hospital .. 276 Swathi T M, Khyathi G V

57. Effects of Nudge and Purchase Intention in Online Purchasing of Electronic Products 282 A. Binu Christeena, S. Preetha

58. Discharge Planning Model with Approach of Method in Improving Patients' Readiness for Discharge in Hospitals 288 Nurul Jannah, Tintin Sukartini, Abdul Aziz Alimul Hidayat

59. Study of Model Climate Maps Using Geographic Information System (G.I.S) 293 Ali Karim Mohamed, Mahmoud Mohammed Al-Shammari, Ali Jabbar Abdullah

60. Impact of Terrorism Act on Child Psychology and Post-Traumatic Stress Disorder 298 Afkar Fadhil Kareem Al-zzawi 
61. The Sociopragmatics of Preaching in an American Christian Sermon 303 Ahmed Sahib Mubarak, Hawraa Jabbar Rahi

62. The Effectiveness of Extract Klika Streculiapopulifolia Cream on the Collagen of Albino Mice against Ultraviolet B Radiation 309 Nur Khairi, Suryani As 'ad, Khairuddin Djawad, Gemini Alam

63. Polymerase Chain Reaction (PCR) Method for Identification Gene Escherichia coli and Officer Depot Behavior in Drinking Water Refill 315 Alfina Baharuddin

64. Assessment of Eu-152 Nuclide Contaminated from Radioactive lightning Rods in Soil Samples at Kasra and Atash in Baghdad ..... 321 Suha Hadi Kadhim, Inass Abdulah Zgair, Rukia Jaber Dosh, Leith Hani Rasheed, Ali Abid Abojassim

65. Increased Expression of Interleukin 13 in Iraqi Patients Suffer from Ulcerative Colitis 326 Ali J. Eidan, Haider M. Haloob, Kalid N. Alazawy, Ali M. Hasan

66. The Protective Role of Hydatid Cyst against Colorectal Cancers 332 Asmaa Murtadha Mohammed, Dhamiaa Makki Hamza, Sabah Neamah Mohammed

67. Pulp Response Capped by Brain Derived Neurotrophic Factor (BDNF) .... 337 Athraa Y. Al-Hijazi, Mukhaled L Ali, Dhuha M Hasan, Abdulla MW Al-shamma

68. Quality of Food Bacteria in School Snacks and Canteens in East Jakarta Health Office Working Area in 2017 341

Bukroanah Amir Makkau, I Made Djaja, Budi Hartono

69. Borax Content in Foods Sold in a Campus and Its Trader Characteristics 346 Fany Saymona Fauzi, Dewi Susanna

70. The Condition of Sanitation Facilities with Escherichia coli Contamination on Food at University Cafeteria 2015 350 Bellini Simangunsong, Dewi Susanna

71. Method and Frequency of Stethoscope Cleaning among Respiratory Therapists in Intensive Care Units at KAMC, Riyadh

Fayz S. Al-Shahry, Fahad Holil Al-Enazi, Nawaf Abdul-alkarim Al-Naam, Saleh Aloraibi

72. Hepatoprotectie Effect of Bromelain against Gentamicin-Induced Hepatic Damage in Rats 358 Hawraa M. Murad, Jawad Kadhim Faris, Hawraa H. Naji, Firas Hussein Kadhim al-bawi, Nadya Jamal Ibrahim

73. Acute Appendicitis Versus Ruptured Ovarian Cyst in Female Patients Presented as Acute Abdomen Pain 364 Wisam Mahmood Aziz, Hayder Adnan Fawzi

74. Effects of Health Promotion Behavior, Self-Esteem and Social Participation Activities on Life Satisfaction of Elderly Men 368 A Reum Lee, Hee Kyung Kim

75. Change of Brief Psychiatric Rating Scale (BPRS) Value with Spiritual Qur'anic Emotional Freedom Technique (SQEFT) Therapy on Mental Disorder Patient 374 Lilin Rosyanti, Indriono Hadi, Jayalangkara Tanra, Asadul Islam, Rosdiana Natzir, Muhammad Nasrum Massi, Faizal idrus, Burhanuddin Bahar 
76. An Empirical Analysis Research on the Characteristics of Elderly Welfare Organizations on Job Fit and Contextual Performance

Il-Hyun Yun

77. A Study on the Effect of Job Performance on Emotional Labor, Career Turnover Intention, Job Stress, Growth Need Il-Hyun Yun

78. Application of Digital Rubbing Massage in Pain Level, Comfort, and Duration of Labor Phase Sudirman, Sumarni, Hartati, Hendra M., Ismi Rajiani

79. Using Propensity Score Bootstrapping on Determining the Model of the HIV/AIDS Patients' Assistance 396 Mahdalena, Mahpolah, Ismi Rajiani

80. ARCS Module (Attention, Relevance, Confidence, Satisfaction) to Increase Classroom Motivation for Pregnant Women at Public Health Center Agustine Ramie, Mahdalena, Hammad, Ismi Rajiani

81. Interprofessional Education Module in Achieving Ethics/Values, Roles, Responsibilities, Professional Communication Competencies, and Team Collaboration among the College of Health Students 406 Neny Triana, Ismi Rajiani

82. Anxiety Level of Dental Care among Adolescents in Kepulauan Selayar District Lilies Anggarwati Astuti, Nurnaeni, Faiqah Umar, Hasanuddin Tahir, Asmawati Amin

83. Baby Massage With Common Cold Massage Oil on Temperature Change, Pulse Rate, Frequency of Breath, Sleep Quality and Number of Streptococcus Bacteria in Toddlers with Acute Respiratory Infection ...... 413 Melyana Nurul W, Fatatu Malikhah, Kusmini Suprihatin, Sutarmi

84. Risk Factors Affecting Attention Deficit Hyperactivity Disorder among Early Childhood in the Agricultural Area in Indonesia 417

Istiklaili F., Suwandono A., Suhartono S., Widyorini E., Saputro D.

85. Maternl and Neonatal Outcomes of Elective and Emergency Cesarean Sections

Esraa Abdulkareem Mohammed

86. Comorbidities of Phototherapy Used in Neonatal Jaundice in Diyala Governorate, Iraq 428 Saif Hakeem Tofiq, Kareem Assi Obaid, Mazin Razooqi Mohammed

87. Effect of Thyroid Disorder on Liver Function and Some Immunological Parameters Jamela Jouda, Majida G. Maghtoof, Alia Essam Mahmood Alubadi, Youns Atiyah Kamil

88. The Presence of Pathogenic Leptospira sp. in Water Bodies in Klaten District 439 Novia Tri Astuti, Mateus Sakundarno Adi, Yuliani Setyaningsih, Martini, Lintang Dian Saraswati

89. Dialectic Unity between Threat and Division Sociological Study 444 Majida Shaker Mahdi

90. Job Demands, Low Back Pain, and Job Crafting Behaviors: A Proposed Framework 449 Malek Ahmad Al-Natour, Nor Azimah Chew Abdullah

91. "Educational-Staff Knowledge and Attitude towards Antibiotic Use in Technical Institute of Karbala" . 455 Maytham Salim AL-Nasrawii, Ali abd Al-Latif. G. Mohammed, Mohammad Abdul Baqi Abdul Mohsin, Mohammed A.Merzah 
92. Intervention of Sexual Abuse Prevention for Mother of Children with Mental Retardation in Payakumbuh Indonesia 2016 461

Meri Neherta, Esthika Ariany Maisa, Yulvika Sari

93. Prenatal Tobacco Exposure and Neonate Birth Weight

Mery Ramadani, Budi Utomo

94. Influence of Firm's Intangible Assets Intensity on Stock Prices Volatility: Evidence from Emerging Market of Pakistan

Muhammad Ramzan Mehar, Huda Tahir, Mariam Nazeer

95. Perception of Job Characteristics and Internal Motivation in Medical Records Staff .

Khadije Sadeghi, Roxana Sharifian, Zahra Mahmoodzade Sagheb, Nasrin Shokrpour

96. Influencing Factors and Microbial Agents Which Contribute to Acne among Students from Pathological Analysis Department/Kufa Technical Institute\Al- Najaf Government 484 Noor Ismeal Nasser, Ahmed Abdul Hasan Mohsin, Thuraya Aamer Habeeb, Maysoon Khudair Al-Hadrawi

97. Analysis of Factors on Reward System in the Hospital 490 Nursalam Nursalam, Berlian Yuli Saputri, Yanis Kartini, Tintin Sukartini

98. Model Development of Nursing Service Loyalty 495 Ahsan Ahsan, Pratiwi Y, Nursalam Nursalam, Ferry Efendi

99. Occupational Health Issues Faced by Women in Spinners 500 R.Vettriselvan, Antony Jesu Rajan FSA., Arunkumar N.

100. Association of HLA-DRB1 Alleles with Allergic Asthma and Total Serum IgE Levels in Iraqi Adults Patients 505 Ali J. Eidan, Raad A. AL-Harmoosh, Zainab J. Hadi

101. The Role of Serum and Follicular IL-1Beta in Predicting the ICSI Outcome in Infertile Women 511 Rihab Abbas Ali, Sahib Yahya Hasan Al-Murshidi, Dalal Mahdi Al-jarah

102. Factors Related to the Satisfaction of BPJS Participants on Outpatient Services in the Regional General Hospital Dr. H. Moch Ansari Saleh Banjarmasin 517 Risa Fariyana, Roselina Panghiyangani, Bahrul Ilmi, Husaini, Meitria Syahadatina Noor

103. Increasing of Nutrition Status of Pregnant Women after Supplementation of Moringa Leaf Extract (Moringa Oliefera) in the Coastal Area of Makassar, Indonesia 521 Nadimin, Venni Hadju, Suryani As 'ad, Agussalim Buchari, Irmawati Haruna, Rudy Hartono

104. Assessment of the Effect of Diyala River upon the Quality of Tigris River in Baghdad Province by National Sanitation Water-Quality Index (NFS-WQI)

Luma H. Alazawii

105. Determination of the Radiation of Alpha Particles in the Air of Primary School Buildings in the City of Karbala 531 Abdalsattar Kareem Hashim, Sara Salih Nayif

106. The Influence of Organizational Pride on the Performance of Lecturers in Health at the Nahdlatul Ulama University in Surabaya 538 Ima Nadatien, Seger Handoyo, Widodo J. Pudjirahardjo, Yusti Probowati 
107. The Effectiveness of Using Direct Composite Veneer Template System in Restoring Anterior Teeth ..... 543 Sri Wahyuni, Saluna Deynilisa, Ismalayani

108. A Study on Breast Cancer Awareness in Female Students of Begum Rokeya University, Rangpur:

A Cross-Sectional Study

Sukanta Das, Mst. Sirajum Munira, BK Chakravorti

109. Failure of Speed oligo Mycobacteria to diagnose Mycobacterium tuberculosis Complex

Directly from Sputum Samples

Tarig MS Alnour, Faisel Abuduhier, Eltayib H Ahmed Abakur, Fahad MA Albalawi, Khalid AS Alfif,

Bernard C. Silvala

110. Body Fat Composition as a Determinan of Cognition Functions in Elementary School Students 557

Tria Wahyuningrum, Lida Khalimatus Sakdiyah, Rina Mardiyana

111. Factors Associated with the Knowledge and Attitude Towards Breastfeeding in Thai Grandmothers of

Pregnant Adolescents 560

Wilasinee Bootsri, Surasak Taneepanichskul

112. Cross-Sector Collaboration Indicators Development of HIV-AIDS Prevention Program in Indonesia ... 566 Balqis, Hasbullah Thabrany, Kemal N Siregar

113. The Relationship between Ventilation with Excess Cancer Risk (ECR) of Benzene at the Shoe Home Industry in Romokalisari Surabaya 572

Bachtiar Chahyadhi, Abdul Rohim Tualeka

114. The Prevalence of Oral Manifestation in Transgenders with HIV/AIDS in Surabaya, East Java, Indonesia 577 Bagus Soebadi, Adiastuti Endah Parmadiati, Hening Tuti Hendarti, Desiana Radithia, Diah Savitri Ernawati

115. Evaluation of the Health Policy Implementation of Indonesian Social Insurance Administration Organization in Primary Health Care Facilities 581

Supriyana, Edy Susanto, Irmawati, Bernadus Rudy Sunindya, Asep Tata Gunawan, Ismi Rajiani

116. The Relationship between Environmental Sanitation to the Incidence of Hepatitis A in Rural Areas of Central Java, Indonesia 585

Teguh Widyanto, Marsum, M. Choerul Anwar, Subinarto, Ahmad Fikri, Asep Tata G, Ismi Rajiani

117. The Correlation between Green Open Space with Carcinogen Toxicity Score of Benzene in Shoes Home Industry Surabaya 589

Nima Eka Nur Rahmania, Abdul Rohim Tualeka

118. Frequency of Cardiac Troponin T (TNNT2) Polymorphism, a Dilated Cardiomyopathy Gene in Tabuk Population 594 Muhammad Tariq, Khalid Fandi, Rashid Mir, Yassir Birema, FM Abuduhier

119. SLC2A2 Gene (Glucose Transporter 2) Variation is Associated with an Increased Risk of Developing T2d in an Ethnic Population of Saudi Arabia 600

Fahad M Almutairi, Rashid Mir, Faisal Abu-Duhier, Roaid Khan, Khalid Harby, Imadeldin Elfaki

120. A Content Analysis of Original Research Articles on Public Health Published in an International Journal:

The Case Study of Thailand 606

Sunanta Wongchalee, Orapin Laosee, Ratana Somrongthong 
121. Study of Mental Health and Attitude towards Psychological Help Seeking among Management and Science University Students

Bavani A/P Raman, Venkata Pavan Kumar Sriperumbuduru, Hasanain Faisal Ghazi, Fazna Saleem, Nava Jyothi Dalayi

122. Acute Lung Rejection: An Important Factor for Long Term Survival in Lung Transplantation Zulkifli Amin, Ignatius Wuryantoro, Ceva Wicaksono Pitoyo, Elvina Johanna Yunasan

123. The Incidence of Stevens-Johnson Syndrome and Toxic Epidermal Necrolysis in Dr. Saiful Anwar General Hospital Malang, Indonesia from 2012-2017

Safrina Dewi Ratnaningrum, Diana Lyrawati, Sinta Murlistyarini, Nurdiana, Tommy Alfandy Nazwar

124. Dynamic Transmission of Dengue Hemorraghic Fever and Climate Variability Patterns in Jakarta 628 Haryoto Kusnoputranto, Margareta Maria Sintorini, Suyud Warno Utomo, Nurusysyarifah Aliyyah, Epi Ria Kristina Sinaga, Okky Assetya Pratiwi

125. Knowledge about Lung Cancer and Awareness of its Risk Factors among the University Students 633 Ashok Kumar Jeppu, Nur Atikah Binti Mohamed Jailani, Kavitha Ashok Kumar

126. Community Treatment Security Index in Makassar City 638 Rusli, Chatarina U. Wahyuni, Suharjono, Hari Basuki Notobroto, Agust Dwi Djajanti, Rudy Hartono

127. Early Detection of Risk Factors and Severity of Airway Obstruction Through Measurement of Critical Values of FVC and FEV ${ }_{1}$ on Bus Terminal Officers 642

Sudiro Sudiro, Martono Martono, Nursalam Nursalam, Ferry Efendi 


\title{
Indian Journal of Public Health \\ Research \& Development
}

\author{
www.ijphrd.com \\ CONTENTS
}

Volume 10, Number 01

January 2019

128. Vitamin D Deficiency in Recurrent Urinary Tract Infections in Children Under 5 Years Old in Salah

Aldeen General Hospital 647

Marwa Faiz Abdul Ghani, Ashoor R. Sarhat, Mohammed Muhsin

129. Urinary Tract Infection in Malnourished Children Under 5 Years in Tikrit - Iraq 653

Mohammad Muhsin, Ashoor R. Sarhat, Marwa Faiz Abdul Ghani

130. Assessment of Knowledge of Mothers Toward Caring of their School Age Children with Thalassemia at Maternal and Child Babylon Teaching Hospital

Abdulmahdi A-Hassan

131. Brain MRI Hyperintensity in Iraqi Migrainuers

Hasanain Ahmed Jasim, Wahab Razzaq Ebdan, Osamah Ayad Abdulsattar

132. (ViewPlus IVEO) Device Effictiveness on Improving Visual Disabilities Students Skill

Rend Haider Hashim, Haidar Tarek Kazem, Jalal Aziz Farman

133. Affects Different Cultures Media and Physical Factors for Growth Pleurotus ostreatus and Pleurotus eryngii 675

Shahad Ahmed, Nida'a Shihab Hamed, Abeer Fauzi Al-Rubaye

134. Attitudes of Nursing and Medicine Undergraduates Students towards Mental Illness at Kirkuk University

Nashwan Nadhim Hasan, Omed Hamarasheed Mehammed-Ameen, Suhailah Mohammed Ali

135. Effectiveness of an Education Program on Dietary Regimen of Patients with Myocardial Infarction in

Al Nasiriyah Hospitals 684

Qasim Ali Khasal, Hussein Hadi. Atiyah

136. Emotional Stability among Applied Scientific Fifth Grad Students and its Relationship to

Self-esteem

Jamal N. Abdulkadhem, Mohammed Kadhim Mantoob

137. Epidemiology of Developmental Delay among Children in Al-Batool Teaching Hospital in Ba'aquba-

Iraq 695

Ashoor R. Sarhat, Saif Saad Jihad, Sarab K. Abdal Rahuman

138. Professional Competencies and Thinking Methods among High School Teachers in Iraq 701

Wijdan Nader Al Rikabi, Dihya Uweed Al Arnoosy 
139. Serum and Salivary Cancer Antigen 125 in Non-Hodgkin Lymphoma Patients Received

Chemotherapy

Faris Abed Hatem, Ameena Ryhan Diajil

140. Taxonomic Study for the Genus Bupleurum L. (Apiaceae) in Iraq using chloroplast gene RPL16 .. 713 Ban.A.H. Al-Khafaji , Muthik A.Guda, Aboothar Ha. Al-Edhari, Attyaf J. T. Altamimi

141. The effect of Demarketing in Reducing Consumption of Medical Products through Consumer Culture (Applied Study in the Public Health Sector / Babil Governorate)

Zeinab Abdul Razzaq Aboud, Shafaa Turki Ayyez

142. The Effect of the Computer Program is Interactive in the Achievement of Students of the Faculty of

Basic Education in Teaching Methods 723

Riad Hataf Obeid, Amina Hatem Abdel Wahid Al-Sayegh

143. The Effectiveness of Interactive Technology in the Students' Achievement of College of Basic Education in the Curriculum of Educational Techniques 728

Mashriq Muhammad Mijul Al-Jiboury, Shafaa Qhani Radhi Al-Shammari

144. The Effectiveness of Teaching in the Gibbs Model in the Decision-Making to Solve the Environmental Problems among Students of College of Education 732

Ariff Hatim Hadi Al- Jubouri, Muayad Hussein Moheisen Al- Jubouri

145. The Historical Narrative in the Repentance of Some Companions in the Book of Tawabeen Ibn

Qudaamah 737

Hussein Mohammed Ali

146. The Impact of Communication Strategy in the Achievement of Students in the Fourth Grade Faculty of Education in the Measurement and Evaluation 741

Ibtisam Al-Zuwaini, Raad Taleb Kadhem

147. The Impact of the "Cognitive Conflict" Strategy in Correcting the Geographical Misconceptions of Second Intermediate Students 745

Karem Obyes Abuhillail

148. The Effectiveness of Multimedia Software in the Achievement of Students of the Faculty of Education in the Curriculum and Teaching Methods 751 Mashreq Mohammed Majoul, Muna Mohammed Hassan Abdul Ghani

149. A Study of the Vertical Position of the Mental Foramen using Cone-Beam Computed Tomography 756 Osamah Shanta Dhumad', Saif S. Saliem

150. Accuracy of FNAB in Diagnosis of Breast Lump 760 Sarab K.Abedalrahman, Najim Abid Issa Al-Khalidy, Ali S. Al-Hashimi, Jawad K. Al-Diwan

151. Anterior Loop Presence and Extension Using Cone-Beam Computed Tomography 764 Osamah Shanta Dhumad, Saif S. Saliem

152. Assess the Level of Knowledge Regarding the use of Anticoagulant Medications among Cardiac Patient in Missan Governorate 768 Mohannd A. L. Khafel, Haleema Yousif

153. Assessment of the Client's Psychological Wellbeing at Outpatient Consultancy Clinics of Al -Sadder Teaching Hospital in Al Amara City 774 Mizher Khlif Hsony Al Rishawi, Ali Kareem Al-Juboori 
154. Combined Dexamethazone/Chlorpheniramine Mouth Rinse Effect on Candida Albicans and sIgA in

Patients with Recurrent Aphthous Ulceration ................................................................................... 780

Mohanad Safwan Aldarraji, Jamal Noori Ahmed

155. Determination of Menopausal Symptoms and Their Effect on General Health Related Quality of Life among Women Attending Teaching Hospitals in Al-Hilla City 786

Wafaa Ahmed Ameen, Muna Abd-Al Wahab Kheleel

156. Eczema, It's Types, Microbiological Causes and Treatments 793

Zahraa Ali Abdulsahib

157. Educational Institutions Teachers' Skills Hope in Babil 798 ALA Mansour Abbas, Imad Hussein almarshadi

158. Effectiveness of an Education program on Nurses knowledge toward Prevention of Complications Related to Valvular Replacement Surgery at Surgical Department in AL-Nasiriyah Heart Center .... 802 Douaa Rasool Abbas, Aqeel Habeeb Jasim

159. Effects of Women's Education on Child Care and Child Mortality 810 Amean A. Yasir

160. Estimation of $\boldsymbol{H S V}$-1 and $\boldsymbol{H S V}$-2 in Chronic Periodontitis in Babylon Subjects 815 Younis Abdulridha K. Alkafaji, Mahdi Yakoob Kzar, Zahraa Dhafer Shams AL- deen

161. Health Beliefs of Patients with Coronary Heart Disease toward Secondary Prevention: The Health Beliefs Model as a Theoretical Framework 821 Hassan Abdullah Athbi, Huda Baker Hassan

162. Health Status among Patients with Percutaneous Coronary Intervention at Cardiac Centers in Baghdad City 827

Kalida Alwan Mansour, Mohanad F. Al-Sarraf, Massara Abdullah Najm

163. Management of Overweight and Obesity in Adults in Baghdad City 835 Khaleel M. Mahdi

164. Molecular \& Antibiotic Sensitivity Pattern Study of Acute Otitis Media, Tonsillitis \& Periodontitis among Different Ages of Patients of Al-Hashmia General Hospital, Primary Care Centers \& Private Clinic in Babylon Province

Ali Malik Saad, Ali Kadhim Aljarah, Nebras Mohammed Sahi Alkhafaji, Wurood Alwan Kadhim

165. Preferred Learning Style among Middle School Students in the Center of Babylon Governorate and Their Relation to Gender 846

Omar Falah Awad, Ameer Mohammed Ali Rasool

166. Quality of Life for Adolescent Clients Who Undergone Bone Marrow Transplantation at the Specialized Bone Marrow Transplantation Center in Baghdad City: A Cross Sectional Study 852 Fadhel Farhan Kadhum Al-Bahadli, Mohammed Fadhel Khalifa

167. Quality of Life for Adolescent Clients with Hypermobility Syndrome in Baghdad City: A Cross Sectional Study 858 Aqeel Abdul Azeez. Hasan, Hala Saadi. Abdulwahd

168. Quality of Life for Adolescent Patients with Hypermobility Syndrome in Baghdad City: A Cross Sectional Study 864 Aqeel Abdul Azeez. Hasan, Hala Saadi Abdulwahd 
169. Relating Body Image with Self-esteem among Patients Seeking Aesthetic Surgery in Baghdad City 870

Iman Hussaein Alwan, Maan Hameed Ibrahim Al-Ameri

170. Risk Factors Associated with Epilepsy among Children in Al- Najaf Province: A Case

Control Study 877

Halah Basim Jawad Mohammed, Shukriyia Shadhan Chyad Al-Ogaili

171. Self - Efficacy of Sickle- Cell Anemic Adult Patients at Blood Disease Wards in Baghdad Teaching Hospitals 883

Suad Hassoon Khudhair

172. Study and Identification of Parasites (Protozoa) in Sampled in Filtered Water of Baghdad 889 Safa Tawfeeq Whaeeb

173. Attitudes of Male Students Toward Women Violence at University of Kufa 893 Fatima Wanas Khudair

174. Comparative Study on the Protective Effect of L-Carnitine in Combination with Beta-Carotene against Overdose Acetaminophen Induced Hepatotoxicity and Nephrotoxicity in Adults Male Rats 897 Bassim Khamess Kuoti Al-Rekabi, Hatim A J Al-Shwilly

175. Effect of physical effort according to (Fartlek Training Method) on the Flow and the Speed of Blood and the Mechanical and Chemical Energy for the Heart Muscle of the Football Players 903 Ammar Jassim Muslim, Mohamed A. Shood, Ahmed Sikban

176. Effects of $\boldsymbol{E R U C A} \boldsymbol{S A T I V A}$ Seeds Powder on Performance and Immunity of Broilers 909 Esraa H Shani, Wifaq Al-Bazi, Kadhim S. Kadhim

177. High Risk of Osteoporosis and Related Fractures for Irritable Bowel Syndrome (IBS) Patients 914 Rafid Hadi Hameed

178. Serum Vitamin D Levels in a Sample of Iraqi Female Patients 919 Noor S. Mohammed Ali

179. Vascular Endothelial Growth Factor/Vascular Permeability Factor and VEGF Gene Polymorphisms is Detectable Rheumatoid Arthritis Patients 924 Ishraq Abdul Ameer Salih, Rabab Omran

180. Antibacterial and Anti-Fungal Activity of Methanolic Extract of Passiflora caerulea 930 Niran Kadhim F. AL-Rubaey, Fatima Moeen Abbas, Imad Hadi Hameed

181. Association of Growth Hormone Gene Polymorphism with Birth and Weaning Weight of Nuimi and Awassi Sheep at Kerbala Province 936 Fatima Abd Al-Muhsen, Hikmat S.Al-Nassir, Salam Mirza, Ahmed A. Mnati

182. Cerebral Palsy Epidemiology in Tikrit- Iraq 942 Abid Ahmed, Salman, Muhamed Nasret Arab, Ashoor R. Sarhat

183. Daucus carota: In vitro Antimicrobial Activity and Bioactive Compounds of Methanolic Fruit Extract Using FTIR Spectroscopic Analysis 948

Fatima Moeen Abbas, Abeer Fauzi Shnawa, Imad Hadi Hameed 
184. Detection of Bioactive Compounds of Vitex agnus-castus and Citrus sinensis Using Fourier-transform infrared spectroscopic profile and Evaluation of Its Anti-microbial Activity ................................... 954 Ahmed Hadi Abdal Sahib, Ekhlas Al-Shareefi, Imad Hadi Hameed

185. Detection of Human Bocavirus amongst Kids Tormented by Respiratory Tract Infections in Hilla Town 960 Amal Raqib Shamiran

186. Effectiveness of Educational Program on Nurses' Knowledge regarding Pre and Post-Operative Nursing Management 964 Mariam M.A. Kreem, Rajha Abdul-Hassan Hamza

187. Estimation of Heavy Metal Concentration for Sediments of Shatt Al-Basrah Canal by using Ecological Indices 970

Zahraa Zahraw, Afrah Abd Maktoof, Abdul Hameed M.J. Al-Obaidy, Luay M. Abdul Kareem, Eman Shakir, Sarah Mustafa Hassan

188. FTIR Spectroscopic Analysis of Fruit Extract of Selected Medicinal Plant [Chrysanthemum morifolium] and Anti-Fungal Activity 975

Fatima Moeen Abbas, Abeer Fauzi Shnawa, Imad Hadi Hameed

189. Harpagophytum procumbens and Cordia myxa: In vitro Antibacterial Activity and Bioactive Compounds of Methanolic Fruit Extract Using Fourier-Transform Infrared Spectroscopic Technique 981 Ahmed Hadi Abdal Sahib, Ekhlas Al-Shareefi², Imad Hadi Hameed

190. In vitro Antibacterial and Anti-Fungal Activities of Methanolic Extract of Mentha pulegium 988 Ekhlas Al-Shareefi, Ahmed Hadi Abdal Sahib, Imad Hadi Hameed

191. Phytochemical Screening by FTIR Spectroscopic Analysis and Anti-Fungal Activity of Fruit Extract of Selected Medicinal Plant of Ruta graveolens 994

Ekhlas Al-Shareefi, Ahmed Hadi Abdal Sahib, Imad Hadi Hameed

192. Prevalence and Correlates of Lifetime Water Pipe and Internet Addiction among Attendee in Café in Al-Hilla City 1000 Amean A. Yaser, Ali F. Abdul Hussein

193. Psychological Problems among Infertile Couple with and without In vitro Fertilization Procedure: Comparative Study 1005

Rasha AbudlAzeez Abed, Arafat Hussain Al-Dujaily, Murtaudha Ghanim Adai

194. Screening of Bioactive Chemical Compounds of Orbanche nana Using Fourier-Transform Infrared Spectroscopic Profile and Evaluation of Its Anti-bacterial Activity 1012 Fatima Moeen Abbas, Saba Saadoon Khazaal, Imad Hadi Hameed

195. Synthesis and Antibacterial Activity of Some New Derivatives Containing Thiazole moiety and Study of Their Effects on MAO Enzyme Activity (In vitro) 1018 Amjad G. Eliwi, Asmaa M. Abdullah, Shaemaa H. Abdulsada, Ruba F, Abdaljabar K. Atia, Iman M. Rajab, Zamen Ahmed Hussein

196. The Effect of the Proposed Program for the Development of the Professional Competences for the Students of Colleges of Education for Purely Sciences (Applicants) 1026 Malik Mutlaq, Reyadh Hatif Obaid 
197. The Strategic Impact of Cognitive Metaphors and Picturing the Idea in Creating Writing for the Fourth Scientific Grade Students (Biology) 1031

Dihya Uweed Al-Arnoosy, Mohammed Shaker Nasser, Ali Kazim Al-Khalidi

198. The Strategic Intelligence for the Distinguishing Students in Secondary Level ..... 1036 Rasha Salman Al-Hemyary, Imad Hussein Al-Murshedy

199. Antibacterial Activity of Synergistic Effect of colicin and Gold Nanoparticles against Klebsiella

pneumonia

Zaid shaker Al-mawlawi, Hind Hussein Obaid

200. Assessment of Attention Deficit Hyperactivity Disorders among Primary School Children in AL-Najaf

City 1048

Duaa Abdul Hadi Al-Fatlawi, Arafat Hussein Al-Dujaili

201. Construction a Scale for Dignose Pupils with Exceptional Needs According To

DSM Norm 1053

Safa M. Abdul Razzaq, Abdul Salam Jawdet

202. Encryption Using Zigzag and Sequences of Bio Molecular Information 1058 Rasha S. Ali, Saad N. Alsaad, Noor T. Mahmood

203. Incidence and Antibiotics Susceptibility Pattern of Coagulase Positive and negative Staphylococci amongst (UTI) children in Children Welfare Hospital / Baghdad/IRAQ 1067 Wissam Adnan Dari

204. Investigating EFL Primary Teachers' Difficulties in Language Classroom 1073 Alyaa Ali Abbas, Muna M. Abbas Al-Khateeb, Salih Mahdi

205. Study of the Effect of Aqueous Water Extracts of Pistacia lentiscus Bark on Some Bacteria Causing Oral Infections 1078

Huda Jassim Al-tameme, AIi Malik Saad, Nibras Mohammed Al-khafaji

206. Synthesis and Biological Activity of New Fused Heterocyclic Derived from 4-oxo-2-

phenylquinazoline-3(4H)-carboxamide 1082

Sahar Abdullah Kadham

207. The Developing of Speaking Skill by the Use of Video Supported Learning in English Language of

Primary School 1088

Safa Mohammed Abdul-Ridah, Sura Abbas Obaid, Abd Ali Nayif Hasan

208. The Effect of Using Index Cards Games Technique on Iraqi EFL Intermediate Students' Performance on Writing Skill 1093

Dhafar Basim Ali, Sabeeha Hamza Dehham, Abd Ali Nayif Hasan

209. The Impact of Teaching Literature and Texts Strategy (PQ4R) in the Written Expression of Students in the Second Grade Average 1098 Zaid Bader Mohammad, Noor Mohammad Jassim

210. The Role of Color Doppler Ultrasound in Initial Evaluation of Patients with Priapism: A Cross Sectional Study 1102

Osamah Ayad Abdulsattar, Ahmed Turki Obaid, Hasanain Ahmed Jasim 
211. The Study of Oral Microbiological Changes in non-Hodgkin Lymphoma Patients Receiving Chemotherapy

Faris Abed Hatim, Ameena Ryhan Diajil, Abbas S. Al-Mizraqchi

212. The Wisdom-Based Performance of the Postgraduate Students

Muheab Abd Al-mutelb Bhaa, Kadhem Abidnoor Abidzaid

213. Treating of Wastewater Contaminated with Dyes Using Photo-Fenton Processes

Ahmed Hassoon Ali, Zainab Abdul Razak, Younis Swadi Tlaiaa 


\section{Indian Journal of Public Health Research \& Development}

www.ijphrd.com

Volume 10, Number 1

January 2019

214. Climate Risk and Environmental Determinants on Dengue Transmission 1123

Fazidah A Siregar, Tri Makmur

215. Test of Hepatoprotector Effect of Merak Leaf Ethanol Extract (Caesalpinia Pulcherrima L) with SGPT Enzyme Parameter and SGOT of Induced Parasetamol Heart Rats (Rattus Norvegicus).

Gemy Nastity Handayany, Trimaya Cahya $M$

216. The Role of CYP17 Gene Expression Towards Imbalance of Estrogen and Progesterone Hormones at Luteal Phase in Marriageable Girls 1135

Suriani Bahrun, Suryani As 'ad, Wardihan Sinrang, Ilhamjaya Patellongi, Herlianty, Ferawati Taherong, Nasrudin Andi Mappaware

217. Determine Organic Solven Exposure in an Environmental Laboratory by Chemical Health Risk Assessment (CHRA) 1142

Yuli Irmayanti, Mila Tejamaya

218. Effect of Propolis Combination with Cefadroxil in Accelerating Clinical Improvement in Benign Chronic Suppurative Otitis Media

Cita Nurinsani Akhmad, Irfan Idris, Marianti Manggau, Sutji Pratiwi Rahardjo, M. Fajar Perkasa

219. Differences in the Health Status of Karo Women Consuming Tobacco and Coconut Fronds Shavings in

Sembahe Baru Village, Deli Serdang Regency .....

Ulina Karo-Karo, Ida Yustina, Etty Sudaryati, Fikarwin Zuska

220. Factors Affecting Breast Cancer Incidence in Murni Teguh Memorial Hospital Medan Hasnida, Namora Lumongga, Lubis

221. Confirmatory Factor Analysis Model of Solid Waste in Small Island Makassar City 1166 Makmur Selomo, Anwar Mallongi, Agus Bintara Birawida, Muhammad Arsyad, Tasrum

222. The Effect of Food Practices on Body Mass Index and Infection Disease on Babies Age of 6-12 Months in City of Makassar, 2018 1171 Arman, Sumiaty

223. Analysis of Malaria Incidence Based on Behavioral Factors in the Islands 1178 Irma Muslimin, Andi Salim

224. Changes in Attitudes in Stunting Prevention through ASAKI Animation Media for Pregnant Women . 1183 Andi Salim

225. Determinant Factors of Maternal Mortality from 2016 to 2017 A case-control study in Banjar Regency 1188 Adriana Palimbo, A Ummu Salmah, Anggrita Sari 
226. Identification of Hazard and Risk Occupational Health in Lumu-Lumu Island Fisheries 1193 Lalu Muhammad Saleh, Syamsiar S Russeng, Andi Wahyuni, Muhammad Rum Rahim, Iva Hardiyanti

227. Analysis of Ordinal Logistic Regression Model on Breast Cancer Diagnosis by Birads Mammography 1199 M. Nadjib Bustan, M. Arif Tiro, Suwardi Annas, Adiatma

228. Coping Mechanism of Students Facing the Competency Exams Reviewed from the Factors Influence in Surya Mitra Husada Health College Kediri 1204

Byba Melda Suhita, Sutrisno, Mayta Sari Dwianggimawati, Heri Saputro, Prima Dewi Kusumawati, Lingga Kusuma Wardani

229. Correlation between Pulmonary Tuberculosis (TB) Patient's Characteristics and Role of Supervisor of Drugs Swallowing (PMO) with the Risk of Transmission in Medan City 2017 1209 Sorimuda Sarumpaet, Syarifah

230. Determinants of Occupational Health and Safety Problems among Seaweed Workers in Takalar Regency 1214 Yahya Thamrin, Atjo Wahyu, Masyita Muis, Syamsiar S. Russeng, Agus Bintara Birawida, Hasnawati Amqam, Andi Hardianti

231. Risk Prediction Model of Lung Tuberculosis Using Spatial Approach in the Coastal Area of Makassar City 1220 Stang Abdul Rahman, A. Ummu Salmah, Indra Dwinata, Anwar Mallongi

232. Analysis of Management System of Healthy Aisle Program in Makassar City 1225 Indar, Alwy Arifin, Nurhayani

233. Prevention of Delay of Decision Making as Efforts to Improve The Mother Health in Polewali Mandar, West Sulawesi Indonesia 1230 Apik Indarty Moedjiono, Awaluddin, Healthy Hidayanty, Tahir Abdullah

234. Criminal Liability of Illegal D Rug Traffickers in Makassar City 1237 Indar, Lisar Wirailham, Slamet Sampurno, Nur Azisa, Alwy Arifin

235. Climate Risks and Environmental Determinants on Dengue transmission 1242 Fazidah A Siregar, Tri Makmur

236. Efforts to Improve Knowledge of Dental and Oral of Sangging in Mepandes Ceremony in Kerambitan District Bali Province, Indonesia 1248

Sagung Agung Putri Dwiastuti, Dewi Supariani, Ida Ayu Dewi Kumala Ratih, Anwar Mallongi

237. Relationship of Rainfall, Population Density, and Human Behavior with DHF Incidence in Makassar City 1253 Hasanuddin Ishak, Jum Dewi Sartika, Darmawansyah

238. Ineffective Regulation of Narcotics Crime Prevention (Criminology Perspective) 1259 Amir Ilyas, Rini Anggraeni, Yuyun Widaningsih

239. Influence of Assertiveness Training in Preventing Sexual Harassment in Nigerian Universities as Perceived by Counsellors in Kwara State 1264 David Obafemi Adebayo, Mohd Tajudin Ninggal

240. The Development of Post Traumatic Stress Disorder among Secondary School Students in Borno State Nigeria: A Systematic Review 1270 Zainudin Abu Bakar, Darma Kabiru Rabiu 
241. Influence of Self-Monitoring in Preventing Bullying Behaviour as expressed by In-School Adolescents in Ilorin, Nigeria

David Obafemi Adebayo, Mohd Tajudin Ninggal, Mary Ogechi Esere

242. The Effects pf Perceived Organizational Support and Affective Organization Commitment on Organizational Citizenship Behaviour of Senior Secondary Teachers

Dian Nataly Paramaartha, S.T., M.Pd, Mukhneri Mukhtar, M.Pd, Maruf Akbar, M.Pd

243. Sexuality among Men with Spinal Cord Injury 1286

Padma A. Rahman, Muhammad Uwais Abdul Hakim, Ahmad Zamir Che Daud, Siti Khuzaimah Ahmad Sharoni

244. A Mediated Role of Students New Environmental Paradigm (NEP) Between Environmental Personality and Pro-Eco Behavior 1290

I Made Putrawan, Rizki Ananda

245. Learning Dexterity: A Techno Psycho Social Construct for Measuring the Potential 1296 Nopriadi Saputra, Sasmoko

246. Validation of Environmental Personality (Conscientiousness, Agreebleness, Neuroticism, Openness, Extraversion) and its Effect on Students' Pro-Eco Behavior Mediated By Intention to Act 1304 Fahmi Fahrudin Fadirubun, I Made Astra, Mieke Miarsyah

247. Aggressive Behaviour and Family Structure among Nigerian Adolescents 1311 Mohammed Tajudeen Yusuf, Aqeel Khan

248. School Culture and Instructional Leadership: A Comparison between High-Performing and Low-Performing Urban Secondary Schools

Ghanad, Anahita, Hussin, Sufean

249. Transnational Academic Collaboration for the Development of an Islamic Studies Programme: The Sharing of Experience

Zainudin Abu Bakar, Rohaya Talib, Sanitah Mohd Yusof, Halijah Ibrahim, Noor Azean Atan, Nazrana Haniff, Muhd Hasan Masnin 